\title{
The Relationship between Leader-Member Exchange and Innovative Work Behavior: The Mediating Role of the Voice Behavior
}

\author{
Alptekin SÖKMEN iD a Edip Sabahattin METE iD $b$ \\ a Kastamonu University, Faculty of Tourism, Kastamonu, Turkey. asokmen@kastamonu.edu.tr \\ b Delta Electronics Trading and Industry Company Ltd., Ankara, Turkey. edip@deltaelectronics.com.tr
}

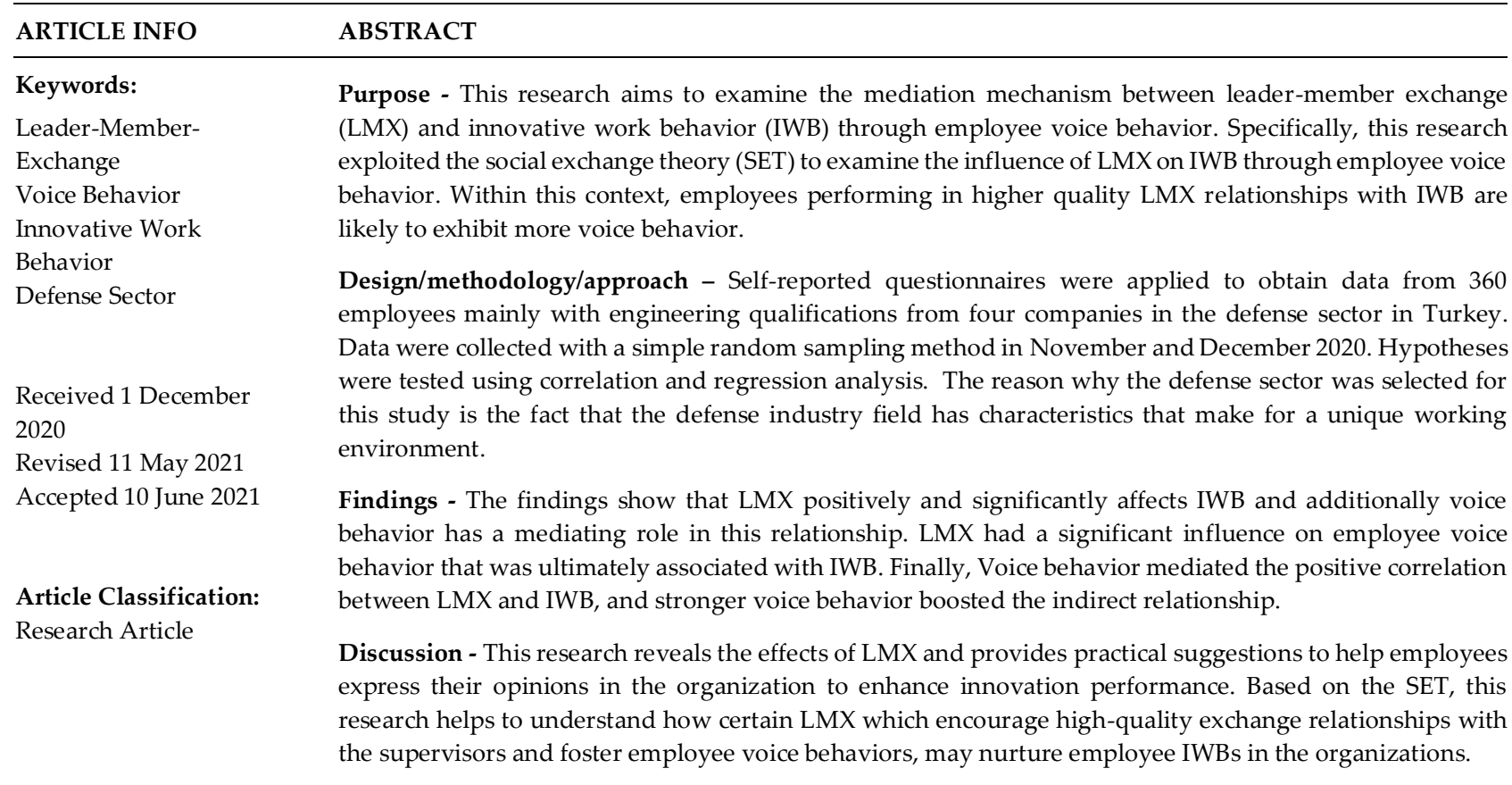

\section{INTRODUCTION}

Researchers (Chowhan et al., 2017; Javed et al., 2019) suggest that today's businesses are required to meet shifting customer demands and maintain a competitive advantage in a rapidly evolving marketplace. Innovation is an indispensable component of organizational performance. In this context, Wang et al. (2017) emphasized the necessity of innovative work behavior (IWB) for employees to survive in contemporary workplaces. According to Martins and Terblanche (2003) and Slåtten et al. (2011), the literature aims at innovation addresses the pivotal role of employees to generate innovation in the workplace. Hence, the organizations have to attempt to foster innovative work behavior (IWB) with employees (Slåtten et al., 2011). It is therefore critical to stimulate IWB in enterprises for steady success. Denti and Hemlin (2012) highlighted the critical role of leaders in promoting and encouraging innovation among team members. Successful leadership functions as a tool in the facilitation of employee creativity.

Gong et al. (2009) and Schermuly et al. (2013) argue that past literature has outlined several leadership theories which support innovation for development; however, have not given enough consideration to LMX despite theoretical rationale. The Social Exchange Theory (SET) (Blau, 1964) is an underlying theory of LMX theory and Graen and Uhl-Bien (1995) posit the unique relationship between the leader and each employee that has been argued as an outcome of expectations related to appropriate role behaviors between leaders and members. Morrison and Milliken (2000) argued that a large part of employees have stick to traditional procedures and refrain from joining in creative activities, even though they have adequate potential to enhance their existing level of IWB. Organizational leaders thus make efforts to promote IWB among their employees 


\section{A. Sökmen - E. S. Mete 13/2 (2021) 1306-1321}

(Bos-Nehles and Veenendaal, 2019). The current research (Javed et al., 2019; Li et al., 2019) have furthermore raised the significance of leadership role in encouraging IWB among their employees (Masood and Afsar, 2017). Leadership is regarded as one of the most widely explored predecessors of IWB. An ample empirical study provides evidence regarding a direct and indirect association between a diverse set of leadership styles and IWB and has shown the complex role of leaders' behavior in enhancing IWB among employees (Lee, 2008). For example, the quality of the exchange link between the leaders and followers is fundamental for the facilitation of extra-role behaviors among employees. In addition, employees' inclination towards raising their voice for the benefit of the organization may reliant upon the quality of LMX. There are studies (Detert and Burris, 2007; Liang et al., 2012) revealing that employees raise their voices in case they feel dissatisfaction associated with existing work processes, methods and difficulties in the workplace and make an effort to display IWB to achieve success in the organization (Mowday et al., 2013), as well. Morrison (2011) described the voice as a deliberate expression of ideas, opinions and information related to work. Voice is an elective and self-initiated behavior that focuses on employees' oral communication to overcome the current conditions through work-related recommendations, thoughts and problems (Morrison, 2011; Ng et al., 2019) by utilizing the lessons learned through the mistakes and shortcomings and enhancing work environments (Wijaya, 2019). It reduces economic and social expenses and improves the value and innovation of the goods and services (Avey et al., 2012; Grant and Rothbard, 2013).

Past research has evidenced that employees' inclination to propose novel concepts to resolve the existing complications contributes to the organization's decision-making process (Morrison and Milliken, 2000), raises organizational conformability (Le Pine and Van Dyne, 2001) and obtains upgraded growth opportunities (Dutton and Ashford, 1993). Nevertheless, a larger part of employees remains silent although they have difficulties or fundamental issues for organizational growth (Morrison, 2011). In these circumstances, the leadership type and the quality of the correlation between the supervisor and the subordinates can evidence more productivity for stimulating IWB among employees. But there is adequate empirical proof about the immediate correlation between voice and IWB, but the structure through which voice may increase the correlation among LMX and IWB need more consideration. In particular, the mediating role of voice behavior between LMX and IWB necessitates extensive investigation.

The leaders are the exceptionally efficacious and dominating characters who impact the behaviors of employees. The employees' belief of experiencing safe or unsafe while boosting their voice for certain organizational gain may depend on the situations regarding the quality of exchange involvement with their leaders (Detert and Burris, 2007; Mackey et al., 2018). Thus, leadership types that boost the quality of exchange relationships and voice behavior may stimulate greater levels of IWB. However, existing studies in the literature have paid little attention to the consecutive relationship between LMX and IWB through Voice Behavior. As a final comment, this research proposes a multi-objective framework. First, the goal of this research is to explore the direct relationship of LMX with IWB and Voice Behavior. Second, this research explores the mediation of voice behavior between LMX and IWB. Organizations should manage their employees to participate in recognizing difficulties and offering ideas for sustainable growth, and this research presents some implications for supporting employee voice in the defense sector. Generating innovative ideas does not threaten existing operations and implementations and voice owners usually evaluate the positive atmosphere in which leaders anticipate, encourage and recognize the voice of the employees (Liang et al., 2012).

\section{THEORETICAL FRAMEWORK AND HYPOTHESES DEVELOPMENT}

\subsection{The Relation Between Leader-Member Exchange and Voice Behavior}

Bauer and Green (1996) define LMX as a dyadic relationship among supervisors and subordinates. According to Dansereau et al. (1975), LMX theory aims at the quality of the dyadic relationship among supervisors and subordinates. Zhang et al. (2015) suggest that supervisors build reciprocally valuable exchange interactions with their subordinates employing several kinds of exchanges and interactions. The leaders are assumed to support their subordinates in high-quality LMX relationships.

Subordinates respond to high-quality LMX relationships by setting in additional periods and endeavor to perform their tasks successfully (Dienesch and Liden, 1986). Furthermore, in low-quality LMX interactions, supervisors and subordinates are limited with contractual relations, which create a downward effect based on 


\section{A. Sökmen - E. S. Mete 13/2 (2021) 1306-1321}

hierarchy and role-defined interaction (Janssen and Van Yperen, 2004). A high-quality LMX relation is combined by reciprocal trust and influence, esteem, loyalty and assuming responsibility to one another (Graen and Uhl-Bien, 1995). According to Van Dyne and Le Pine (1998), employee voice behavior is defined as individuals' inclination to make innovative ideas for improvement and propose adjustments to methods that have become a standard for the organization. The employee voice idea is rooted in the notion that explains frustrated employees' strong desire to voice their suggestions and encourage more adjustments for upgrading the conditions to enhance organizational achievement (Zhou and George, 2001). Van Dyne, Kamdar and Joireman (2008) suggest that voice behavior is displayed by employees voluntarily and is not formally prescribed by a job description; therefore, employees are not obliged to exhibit voice behavior in the workplace. Detert and Burris (2007) argue that employee voice behavior entails risks due to it proposes revisions to existing procedures and techniques related to the organization. Employee voice behavior has positive contributions to the success of the organization (Organ et al., 2005); however, the employees should take into account the potential consequences of their activities, readiness to take risks and most significantly be concerned about the possible negative outcome of their voice (Liang et al., 2012). Establishing a goodquality exchange relationship and having strong relationships with the supervisor may thereby allow employees to reduce the degree of risk concerning voice behavior (Mo and Shi, 2018). Gerstner and Day (1997) suggest that the employees may not willing to increase their voices in case of a low-quality LMX with their supervisors. On the contrary, the supervisors show extra respect, friendliness and trustworthiness to employees who display high-quality LMX with their supervisors. This perspective is consistent with SET which explains that individuals exchange positively when they receive favorable feedback from others.

Hence employees may have the confidence to boost their voice in case there is a high-quality LMX (Gouldner, 1960) since they may have thought that the interaction route between them and the supervisors is open (Botero and Van Dyne, 2009). Empirical evidence in the literature has revealed that employee voice behaviors are altered by supervisors' actions (Detert and Burris, 2007; Graham and Van Dyne, 2006; Zhang et al., 2015). When employees' positive voice is raised along with a high LMX association with the leaders, employees can challenge rules and procedures controlling the organization and leadership by voice behavior (Morrison and Milliken, 2000) and they attempt to facilitate positive and constructive transformations (Zhou and George, 2001).

There are four reasons explains why high-quality LMX can foster employee voice behavior. As the first reason, employees with high-quality LMX have further open contact and interaction with the supervisors, ultimately conducive to occasions to boost their voice (Botero and Van Dyne, 2009). Second, in high-quality LMX, subordinates have more confidence in their supervisors and obtain benefits from intense work assistance and supervisor receptiveness. Botero and Van Dyne (2009) and Hsiung (2012) argue that these qualities give rise to employee perception of little risk or personal cost in voicing their opinions and subordinates feel that their ideas may be recognized by their supervisors. Third, employees feel the necessity to exchange this positive treatment and they will be in search of supporting the organization via their voice behavior when they assume that they are treated favorably (Burris et al., 2008; Van Dyne et al., 2008). Lastly, high-quality LMX signifies that the leader-member association develops to a collaboration level (Uhl-Bien et al., 2000; Hsiung, 2012). Employees, who have high-quality LMX relationships, show a tendency to understand the views and positions of their supervisors and are more likely to raise various propositions to the organization and intend to accomplish organizational objectives that mutually advantageous for subordinates and supervisors (Hsiung, 2012). Several empirical research has revealed that subordinates are highly engaged in employee voice behaviors when they believe that they developed a high-quality LMX relationship with the supervisors (Botero and Van Dyne, 2009; Burris et al., 2008). Hence, Hypothesis H1 is proposed as follows:

H1. Employees' perceptions of leader-member exchange have a significant influence on their voice behavior.

\subsection{The Relation Between the Voice Behavior and Innovative Work Behavior}

According to Amo and Kolvereid (2005), IWB is defined as an employee initiative, which focuses on introducing innovative goods, processes, marketplaces, or a set of related things into the organization. Idea generation, idea championing and idea implementation are the steps generating the process of IWB (Scott and Bruce, 1994) and are efficiently carried out when employees perceive and understand what type of ideas will be regarded as innovative and accepted by their supervisors (Adarves-Yorno et al., 2007; Gabris et al., 2000; 


\section{A. Sökmen - E. S. Mete 13/2 (2021) 1306-1321}

Serva et al., 2005). Employees are the crucial element for innovation in organizations (Huang et al., 2005) since they suggest constructive and innovative approaches to impact organizational efficiency (Bateman and Crant, 1993). Employee voice is a kind of change-orientation behavior (Detert and Burris, 2007), which is vital for the overall productivity of an organization that enables a structure for innovation and fault recognition (Morrison, 2014). In an organization, voice behavior facilitates the discussion of distinctive ideas that have the potential to enhance employees' job performance within an organization (Morrison, 2011). Employees articulate their interest in change if they consider it necessary for current processes within the organization (Guzman and Espejo, 2019). According to Scott and Bruce (1994), these types of actions are fundamental for forthcoming innovative activities in the organization in most cases. Morrison et al. (2011) point out that voice behavior acts as a climbing stage or turning point for IWB. On the other hand, Weiss and Morrison (2019) stated that voice behavior support employees to perform tasks innovatively. It is an interactive process where employees extend imagining and expose their inventiveness, offering innovative suggestions or opinions depending on reactions collected (He, et al., 2020). Weiss and Morrison (2019) remarked that voice behavior provides hints about individuals' capability to make proficient contributions to the organization. Thus, raising voice to allow employees to yield positive outcomes like encouragement, reputation and respect within the organization.

Van Dyne et al. (2003) suggest that it challenges the existing conditions and emphasizes controversy inside the organization, elevating the attentiveness of the employees towards the voicer's attempt in contributing to the organization (Van Dyne et al., 2003). For voicer, this oriented attentiveness, as a response, heightens the possibility of being viewed as reputable and valuable through the support provided by others ( $\mathrm{Wu}$ and $\mathrm{Wu}$, 2019). Managers and supervisors have an obligation to create a positive and supportive work environment, to enable change and motivate their employees within the organization (Delmestri and Walgenbach, 2005; Zhang et al., 2008). Once employees believe that their workplace is portrayed by voice behavior as a group-level attribute (Kremer et al., 2019), their involvement in the activities and innovativeness are increased when they are further motivated to raise their voice (Deci and Ryan, 1987). Under such a scenario, employees may perceive the working conditions being as goodwill displayed by the supervisors and may respond by participating more with IWB to take the necessary measures to improve the current practices and rules that they confronted by increasing their voice. Such a helpful attitude of the supervisors is required, given that employees suggest innovative approaches for work-related challenges rarely, in case of experiencing a conflict or disagreement with the supervisor, the supervisor should display supportive behavior and be cooperative to their employees and abstain from the authoritarian style in such cases (Cheung and Wong, 2011). This approach is consistent with SET and earlier research has found the significant influence of voice on employees' IWB (Dedahanov et al., 2016; Ng and Feldman, 2012). Hence, the Hypothesis H2 is proposed as follows:

H2. Employees' voice behaviors have a significant influence on their innovative work behavior.

\subsection{The Relation Between the Leader-Member Exchange and Innovative Work Behavior}

Scott and Bruce (1994) describe IWB as the problem identification and the creation of new or acknowledged concepts or ideas. According to De Jong and Den Hartog (2007), IWB is defined as the identification of problems and purposeful introduction of new and valuable ideas relating to products, services and workrelated processes within a work function, group or organizational level. In the contemporary world, IWB of employees plays an eminent role in the success of an organization since the innovation capacity of an organization is heavily reliant upon its employees. This can be implied that IWB of employees is a unique main resource for the achievements of an organization in a fast-moving volatile business world (Abstein and Spieth, 2014). IWB incorporates both idea generation and implementation. Singh and Sakar (2012) suggest that employees exhibit IWB when they receive organizational encouragement for the promotion and execution of new suggestions. Being as employees IWB is an underlying factor for organizational accomplishment, previous studies demonstrated that various workplace issues are affecting the exhibit of such behavior, specifically in the context of the supervisor-subordinate relation (e.g. Basu and Green, 1997; Scott and Bruce, 1994). By considering LMX theory, previous research posits that the quality of the relationship displayed by supervisor diversifies among subordinates and individuals with high-quality LMX perceive backing and satisfaction with work relationship based on trust and loyalty (Walumbwa et al., 2010a, b). Employees, who experience high-quality LMX, are emotionally supported by their supervisors and receive loyalty, trustworthiness, caring and obtain work-related data from their supervisors, and in turn, these employees 


\section{A. Sökmen - E. S. Mete 13/2 (2021) 1306-1321}

extend enhanced endeavor and involvement and exhibit IWB and creative performance (Scott and Bruce, 1994).

In line with SET, employees exchange through enhanced endeavor, in-role achievement, engagement, and favorable job-related consequences (Schermuly et al., 2013). Moreover, past research revealed that employees experiencing a high-quality LMX interrelation are mainly focused on engagements beyond regular activities when compared to employees with a low-quality link, who deal with regular activities all the time. Nonroutine missions assist in inducing creative viewpoints while the high-quality supervisor correlation promotes their autonomy and encouragement to experiment and execute novel ideas and acquire effective results (Scott and Bruce, 1994). Even though earlier studies have shown that high-quality supervisory relationships affect the cognitive and emotional reactions of employees (De Jong and Den Hartog, 2007; Schuh et al., 2018) and there is poor knowledge in the literature about the controlling aspect of affective response in the association between LMX and employee IWB (Saeed et al., 2019). The reason why LMX is selected as the most influential leadership type that is capable of boosting IWB is diverse. Because, although transformational, transactional and empowering leadership styles mainly influential in developing novel concepts and opinions, LMX relies on quality affairs, and enables employees to receive social care and endorsement in support of ideas, which thus can be executed successfully (Schermuly et al., 2013).

The research on LMX has revealed that employees who benefit from a high-quality LMX relationship think to be grateful to provide creative contributions by participating in open activities at the workplace (Ilies et al., 2007). Furthermore, flexible communication between the leader and the subordinate will provide an environment for the leader to concentrate on the requirements, potentials and difficulties of an employee in a given task, which might certainly increase the employee's IWB (Muñoz-Doyague and Nieto, 2012). The employee, as a result of a high-quality exchange, benefits access to obvious reactions linked with the creative ideas or a chance to well organize the resources and to obtain expanded support in the period of realizing the solutions. Self-sufficiency, responsibility and joint decision-making are linked in high-level LMX interactions with IWB. (Hammond et al., 2011). The instant changes in technology, the harsh rivalry to innovate repeatedly and often, reduced product life cycles and the high burden on enterprises to react fast and innovatively to recurring routine difficulties caused the organized procedures and systems to fail (Zhang and Bartol, 2010). Hence, employees should execute tasks beyond the routines. They may perhaps explore innovative technologies, propose new practices to accomplish the goals, employ different work processes and explore and obtain vital assets to realize novel ideas (Basu and Green, 1997). Subsequently, IWB is essentially aligned with the vagueness, fuzziness, and uncertainty of innovation. Hence, it can be said that encouraging LMX relationships generate a constructive result on innovative work behaviors as employees acquire further autonomy and make their decision generously in high-quality LMX defined by reciprocated confidence and esteem (Graen and Uhl-Bien, 1995), which are significantly associated with creativity and innovation. Thus, the following hypotheses proposed:

H3. Employees' perceptions of leader-member exchange have a significant influence on their innovative work behavior.

\subsection{Mediating Role of Voice Behavior in the Relation Between LMX and IWB}

According to the leader's mindset, employees decide to offer ideas to work-related difficulties together with novel suggestions for organizational development. These approaches provide the basis for their IWB. Once the leader discovers employees' aspirations and sentiments, which may encourage their impatience to contribute in innovative endeavors to act as inventive at the workplace (Oldham and Cummings, 1996). On the other hand, if leaders make the employees take part in the decision-making process, cause them to be under pressure, meticulously detect and monitor their behaviors, consequently the innovative success of the employees will depreciate (Deci and Ryan, 1987). Especially, the meticulous control of the autocratic style on employees could diminish the quality of LMX among supervisors and subordinates which causes reduced employee voice behavior. Subsequently, the employees might be unwilling to generously voice their views and innovative suggestions due to anxiety, which will eventually discourage IWB (Dedahanov et al., 2016; Gu et al., 2018). 


\section{A. Sökmen - E. S. Mete 13/2 (2021) 1306-1321}

This research underlines that the whole sequential relationship is dependent on a reciprocal dealing among supervisor-subordinate interactions and the voice-based recommendations, in the long run generating IWB among employees. During this series of acts, they are inspired by the leaders and provide feedback by reducing the quality of the LMX with the supervisor or by increasing it. Later, in accordance with the LMX quality, they choose whether to raise their voice for organizational value. Accordingly, they respond by demonstrating a certain degree of IWB (high, medium or low), as expressed previously. Therefore, the following hypotheses proposed:

H4: Employees' voice behaviors have a mediating effect on the relationship between their perceptions of leader-member exchange and innovative work behavior.

\section{RESEARCH METHOD}

\subsection{The Purpose of the Study and Research Model}

This research has the official approval of the ethics commission of Ankara Hacı Bayram Veli University with a document reference: E-11054618-302.08.01-16504 dated 26.03.2021. The primary objective of this research is to examine the relationship between the variables of Leader-Member Exchange (LMX), Innovative Work Behavior (IWB) and Voice Behavior (VB) in the sample consisted of employees from the defense industry. The research model with hypotheses has been developed to illustrate the associations between the variables in line with the theoretical framework (See Figure 1).

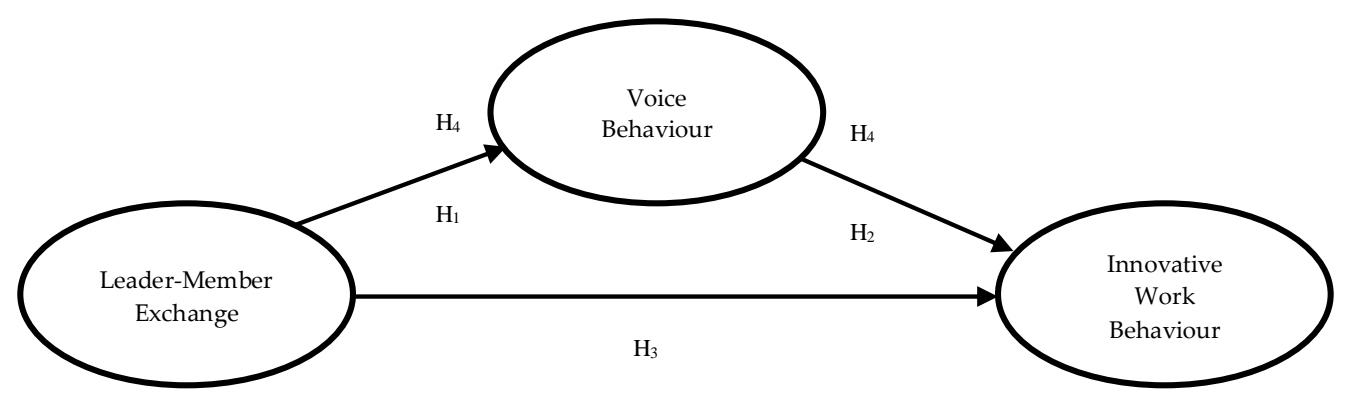

Figure 1: The research model

The research model is given in Figure 1, the hypotheses, and the foundations of the hypotheses in the context of relevant literature are as follows:

H1: Employees' perceptions of leader-member exchange have a significant influence on their voice behavior.

$\mathrm{H}_{2}$ : Employees' voice behaviors have a significant influence on their innovative work behavior.

$H_{3}$ : Employees' perceptions of leader-member exchange have a significant influence on their innovative work behavior.

$\mathbf{H}_{4}$ : Employees' voice behaviors have a mediating effect on the relationship between their perceptions of leader-member exchange and innovative work behavior.

\subsection{Research Sample}

The research was conducted among expert employees from four companies operating in the defense industry and the data were collected via questionnaires with a simple random sampling method in November and December 2020 in a city of Turkey. The population chosen for this study was the technical experts and a significant proportion of technical experts serve an engineering role. The participants were asked to join the study voluntarily. In the specified period, the total number of expert employees working in the departments of the relevant companies was 986 and a total of 360 completed questionnaire forms were returned by the respondents. Demographic questions are asked in the first part of the survey to acquire data regarding participants' age, gender, education level, position and hours of service. The second part of the survey includes statements that measure employees' perceptions of leader-member exchange, voice behavior and innovative work behavior. In this context, the selected sample represents $37 \%$ of the total study population. 


\subsection{Measurement Instruments}

The questionnaire forms used in this survey are composed of 21 items except for demographic questions. 12items Leader-Member Exchange Scale developed by Liden and Maslyn (1998) was used to measure employees' perceptions of LMX. The Leader-Member Exchange Scale includes sample statements such as "I like my supervisor very much as a person." In order to measure the IWB, idea generation sub-dimension, which consists of 3 items, were selected out of 9 items composing Janssen's (2000) Innovative Work Behaviour Scale that includes sample statement such as "I create new ideas for problems difficult issues". VB of employees was measured through a 6item scale developed by Van Dyne and Le Pine (1998). The scale includes sample statement such as "I speak up and encourage others in my work unit to get involved in issues that affect our work." The scales used in this survey were prepared based on Five-point Likert type and each item has a range of answer option from 1=strongly disagree to $5=$ strongly agree. The scales were distributed both in print and in electronic form in an attempt to achieve higher participation.

\subsection{Data analysis}

The acquired dataset in this survey was analyzed by using SPSS 26 software. Demographic data referring to demographic characteristics of employees were interpreted by using frequency analysis and percentage values. Cronbach's Alpha analysis was conducted to determine the reliability of the scales. Correlation and regression analyses were carried out associated with hypothesis testing.

\section{Findings}

\subsection{Validity and Reliability Analyses of the Scales}

The numbers of female and male participants correspond to 92 and 268, respectively. Among those who participated in the survey, $62 \%$ are married, $27 \%$ are single and $11 \%$ are divorced; $26 \%$ aged between 22 and 30 years, $49 \%$ aged between 31 and $39,25 \%$ aged 40 years and over; $8 \%$ have a high school degree, $67 \%$ have a bachelor's degree, $25 \%$ have a master's and doctorate. Of the participants, $32 \%$ served for a period between 1 and 10 years, $46 \%$ served for a period between 11 and 20 years and $22 \%$ served more than 21 years. In the context of getting meaningful responses to survey questions, participants were not requested to provide information regarding their title and department.

Table 1. Reliability Coefficients and Correlation Values of the Variables

\begin{tabular}{|l|l|l|l|}
\hline & 1 & 2 & 3 \\
\hline Leader-Member Exchange (LMX) & {$[0.92]$} & & \\
\hline Voice Behaviour (VB) &, $527^{*+*}$ & {$[0.89]$} & \\
\hline Innovative Work Behavior (IWB) &, $496^{* *+}$ &, $508^{* *+}$ & {$[0.91]$} \\
\hline
\end{tabular}

${ }^{* *}$ Correlation is significant at the 0.01 level (two-tailed), [the values (in parentheses) represent Cronbach's Alpha reliability coefficients]

In this survey, the reliability coefficients for Leader-Member Exchange Scale, Voice Behaviour Scale and Innovative Work Behavior Scale were 0.92, 0.89 and 0.91, respectively. These values show that these scales had acceptably high-reliability coefficients.

\subsection{Tests of the Hypotheses}

Correlation analysis was carried out to demonstrate the associations among the variables. The results of the analysis suggest a positive and significant $(\mathrm{r}=0.527, \mathrm{p}<0.01)$ relationship between LMX and VB and a positive and significant $(r=0.496, p<0.01)$ relationship between LMX and IWB. The results revealed a positive and significant $(r=0508, p<0.01)$ relationship between VB and IWB, as well. 
A. Sökmen - E. S. Mete 13/2 (2021) 1306-1321

Table 2. Regression Values

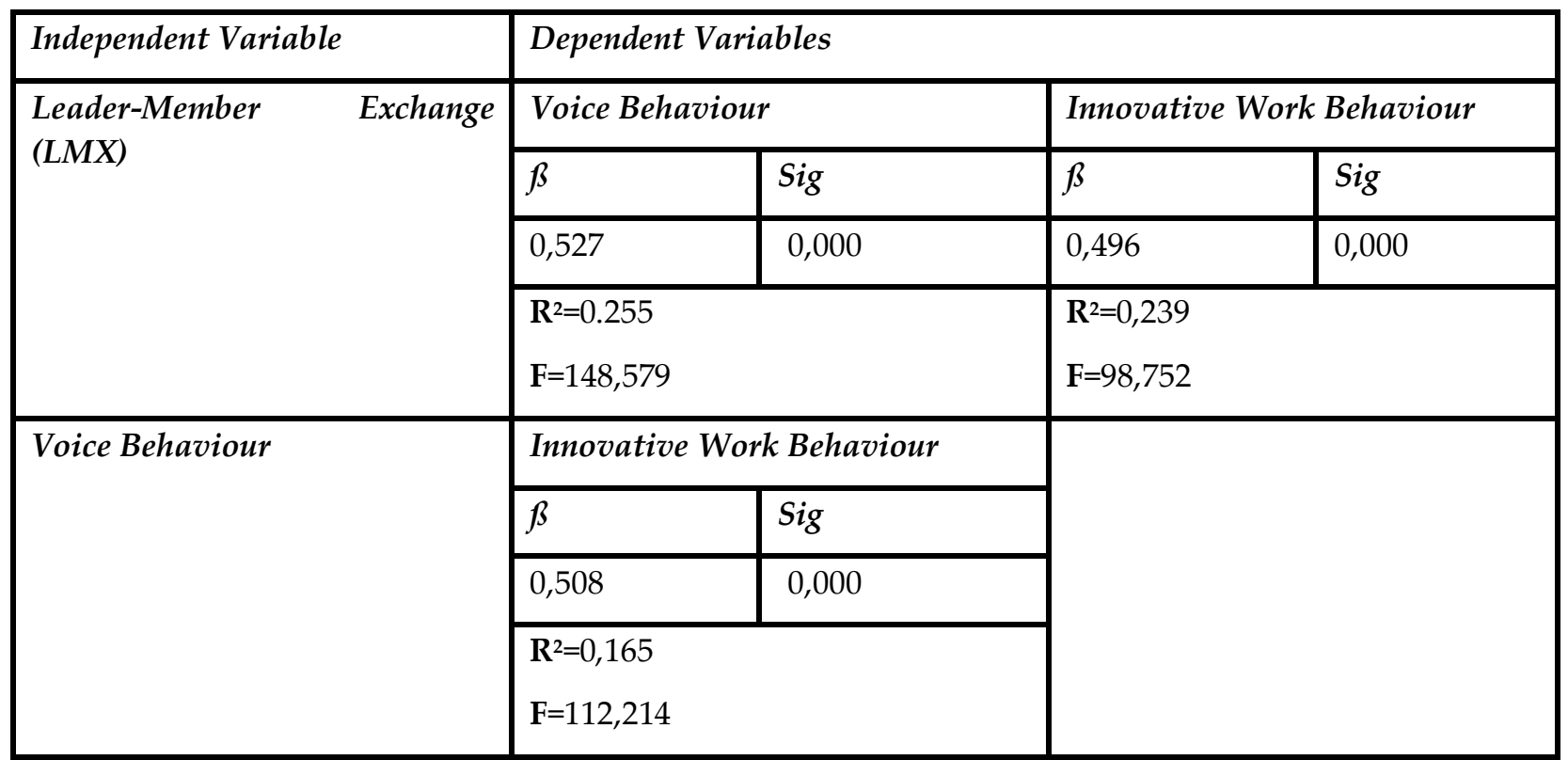

Based on the results of the regression analysis, it can be observed that LMX has a positive and significant influence on $\mathrm{VB}(\Omega=0.527 ; \mathrm{p}<0,001)$ and has $25,5 \%$ explanatory power $\left(\mathrm{R}^{2}=0.255\right)$. The regression results also concluded that LMX has a positive and significant influence on IWB ( $(=0.496 ; p<0,001$ and has $23,9 \%$ explanatory power $\left(R^{2}=0.239\right)$. Hence Hypothesis 1 and Hypothesis $\mathrm{H}_{3}$ were accepted. The results implied that defense industry employees exhibit higher levels of VB and IWB when their perceptions of leader-member exchange increase. The results also show that VB has a significant influence $(B=0.508 ; p<0,001)$ on employees' IWB and has $16,5 \%$ explanatory power $(\mathrm{R} 2=0.165)$. Hence Hypothesis $\mathrm{H}_{2}$ was accepted. Thus, it can be articulated that defense industry employees show higher levels of idea generation dimension of IWB when their VB increases. The mediation analysis method was used to determine the mediating role of VB on the influence of LMX against innovative work behavior (Baron and Kenny, 1986; Hayes, 2009). In this method, the role of a mediator can be determined by using a three-variable model; therefore, the model was generated accordingly. Thus, the following model was tested relating to the mediating effect of VB on the influence of LMX against IWB.

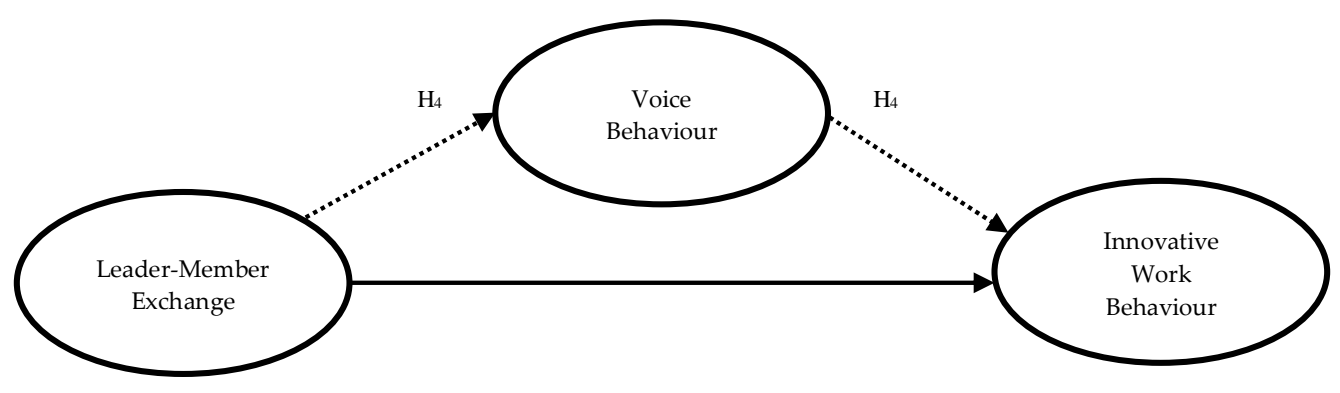

Figure 2. MediatorVariable Model

Based on the given model, the results of regression analysis results suggest that LMX has a significant influence $(B=0.527 ; p<0,001)$ on VB in the first step; LMX has a significant influence $(\Omega=0.496 ; p<0,001)$ IWB in the second step; VB has a significant influence $(B=0.508 ; p<0,001)$ on IWB in the third step.

In the final stage, LMX and VB were incorporated into analysis together and were investigated in terms of their influences on IWB. In this context, the positive and significant influence of LMX on IWB continued whereas the regression coefficient $(B=0.447 ; p<0,001)$ decreased with the inclusion of $L M X$ and VB. The positive and significant influence of VB on IWB continued, however, the regression coefficient $(B=0.389 ; p<0,001)$ decreased. Thus, the results concluded the mediation of VB on the influence of LMX against IWB. Hence, Hypothesis $\mathrm{H}_{4}$ was accepted. 
A. Sökmen - E. S. Mete 13/2 (2021) 1306-1321

\section{DISCUSSION AND CONCLUSION}

IWB is critical for organizational achievement and effectual leadership can encourage it in the organizations (Bai et al., 2016; Li et al., 2015; Wang et al., 2017). This research focused on the present cavity in the literature on IWB (Li et al., 2019) to explicate the effect of LMX in IWB utilizing social exchange theory (SET). SET (Blau, 1984) depicts how social interactions may arise among leaders and the employees in an organization. The results support earlier findings and grant to the research on the correlation among LMX and IWB of employees. This research has revealed that the level of LMX with specific efforts on an individual may predict the IWB of the employees positively. This is in accord with prior research that LMX is a crucial antecedent of employees' creative effort contribution (Hassanzadeh, 2014; Volmer et al., 2012). This research likewise proved a significant correlation between LMX and employee voice behavior. Mainly, the research explored the involvement of LMX on IWB thru a mediation structure of voice behavior. The statistical findings of this research offer intriguing conceptions about the function of voice behavior on IWB and LMX which maintain the viewpoint of SET. The conclusions also coincide with the standpoint of SET and it posits that the subordinates may perceive the high-quality interaction with their supervisor as an incentive and be conscious of liability to reciprocate by raising their voice in favor of the organizational gains.

This research posited four significant contributions. Firstly, this research discovered a positive association between LMX and IWB aimed at employees. This result supports the study of Schermuly et al. (2013) who observed the quality of interactions among employees and close supervisors' prominence creative effort participation and task engagement. SET encourages a correlation created by LMX towards innovation since the degree of the correlation created by the leader and the employee greatly influences employees how to behave and the response of the organizations accordingly (Graen and Uhl-Bien, 1995). Consistent with numerous research (e.g. Schermuly et al., 2013; Volmer et al., 2012), this research outlined the importance of leadership as a very significant antecedent in IWB of employees along with supervisors' collaboration is very essential during the innovation process. The reason for this could be that the employees expect most probably a positive approach from the leaders. (Gumusluoglu and Ilsev, 2009). Therefore, the existence of the dyadic relationships may create a crucial demand for the enthusiasm of the employees employing Innovative Work Behavior and the level of the quality and dynamics of the relations between the employees and leaders. Secondly, the results of this research also adhere to earlier research supporting that leaders reconstruct employee voice behaviors (Detert and Burris, 2007; Graham and Van Dyne, 2006; Zhang et al., 2015). Likewise, a positive correlation between employee voice and IWB was also examined through these findings which are consistent with the earlier empirical results (Dedahanov et al., 2016; Ng and Feldman, 2012). Greater awareness of voice signifies employees' inclination to struggle the status quo by voicing their concerns (Liu et al., 2010; Walumbwa and Schaubroeck, 2009) by way of task-associated proposals, concepts and questions (Morrison, 2011; Ng et al., 2019). Subsequently, they consider themselves more compelled to display an elevated degree of IWB. Third, this research hypothesized that the level of LMX perceived by the employees has an indirect effect on IWB via employee voice behavior as well. The results indicate that LMX impacts IWB only when employees are certain about their self-confidence concerning personal capabilities to execute inventive consequences. Consequently, when the interaction between the leaders and followers reached a high degree of quality, a positive effect arises on IWB since it enhances the employee voice behavior. Fourth, this research revealed voice behavior to mediate the link between LMX and IWB. Besides, the data obtained through the mediation analysis showed that voice behavior mediates the correlation between LMX and employee voice behavior as it supports the significant LMX dimension with employee voice. Based on SET, the conclusions clarify that the indirect effect of LMX on employee's IWB through voice behavior is more obvious and constructive during the high level of LMX.

\subsection{Theoretical and Practical Implications}

This research offers crucial visions into essential consequences to be considered in the applications either theoretical or practical. Primarily, studies related to LMX have broadened by showing that LMX can impact employees' IWB by enhancing its relationships with voice behavior. This research offers suggestions on how to proceed with these relations in future studies on the voice behavior displayed by the employees, signifying that employees voice willingly any of the suggestion or opinion once they feel a solid LMX association with 


\section{A. Sökmen - E. S. Mete 13/2 (2021) 1306-1321}

the supervisors. This sort of perception encourages employees to act creatively which consequently boosts IWB. Even though there is broad research on leadership and employee voice (Chan, 2014; Zhang et al., 2015), this research exposed the mediated relationship between LMX and IWB through voice behavior. Although some researchers examined the relationship between LMX and IWB with the role of employee voicing but suggested a necessity for future research to present further theoretical interpretations that clarify why highquality LMX might expedite or hinder employee voice behavior (Gu et al., 2018; Ng and Feldman, 2012; Wang et al., 2017). Hence, this research fills the mentioned gaps and provides a meaningful approach to the literature of IWB as proof concerning a mediator role of voice behavior with LMX.

The prior literature suggested that high-quality LMX substantially boosts extra-role behaviors displayed by the employees (Ilies et al., 2007). If such transparent relationships exist between the leader and subordinates, particular attention is needed by the subordinates for the possible consequences of voicing new ideas (Morrison, 2011). There is a proven case that most employees hesitate to convey their opinions because they assume the risk of a harmful relationship that may occur between the leader and themselves (Morrison and Milliken, 2003). Contrariwise, generating innovative ideas does not threaten existing operations and implementations and voice owners usually evaluate the positive atmosphere in which leaders anticipate, encourage and recognize the voice of the employees (Liang et al., 2012). Additionally, earlier research posits that employees' IWB depends on the two-fold process of idea generation (innovation) and stating these ideas to the leadership (voice) to facilitate the ideas to be implemented (Rank et al., 2004; Zhou and George, 2001). Formerly, (Chen and Hou, 2016) identified the voice as a critical means of merging leadership behavior with IWB displayed by the employees. IWB necessitates bringing valuable ideas to the management, even though those ideas absolutely are not altering the existing practices and methods within the organization (Anderson et al., 2014).

This research exposes that leaders can encourage employees' voice behavior by supplying the necessary assistance, mutual influence, confidence, appreciation and speak competently with their employees. Furthermore, the mediating mechanism of voice behavior on employee's IWB suggests that management has to appreciate employees' sensations and offer more autonomy to voice generously when articulating innovative ideas. Also, this research broadens the literature by advising the organizations that a high level of LMX may influence the distinctive ideas created by employees. Accordingly, the findings can be used to propose a solution to the organizations that can revise the practices, and how the effect of the leader can expedite the necessary approaches for employee participation. For instance, if any organization needs to improve the level of IWB at the workplace, the management has to provide the leaders with the required authorization to reserve certain resources and autonomy. This research exposes also how voice behavior executes a bridge function during the generation of innovation by the employees. Besides, it is instrumental for management to provide the opportunity to their members of the workforce to get involved in the decisionmaking stage of new business attempts, in this manner, enriches employees' perception of being valuable and important in the organization. So, these kinds of management strategies may generate a richer perceived organizational reputation (Fuller et al., 2007). Management should promote employees to voice ideas on how to develop work structures and methods to gain sustainable competitiveness and continued success. These business approaches, integrated with the approach strengthening a high-quality LMX have to encourage voice freedom and enhance the opportunity of voicing exercised by employees.

\subsection{Managerial Implications}

As the findings demonstrate that LMX has a positive influence on the IWB displayed by the employees, managers need to realize that their interactions with the members of the workforce can create significant outcomes utilized by the organizations. Additionally, meta-analytic research (Dulebohn et al., 2012, p. 24) revealed that "LMX quality was positively managed by leaders their instead of members of the organization". Therefore, managers should make an effort to build and keep steady encouraging relations with as many employees as conceivable. To accomplish this objective, managers do not have to take care of all employees equally, however, everyone should feel recognized (Yukl, 2002). Principals may play an imaginative modeling role to motivate their followers that they also become creative and execute innovation. The hands-on trials could be complementary activities to employ creative competency. The mentioned approaches may improve employees' experimental and metacognitive talent, thus fostering creativity and innovative behaviors. So, 


\section{A. Sökmen - E. S. Mete 13/2 (2021) 1306-1321}

managers may resolve the concern and fear of the employees which may occur as a result of the ambiguity of inventive pursuits by presenting guidance and incentives.

\subsection{Limitations and Future Research}

This research has some strong points to draw attention to certain issues. First, even though prior research has mostly focused on mixed employees who can judge the innovative behavior and voice behavior displayed by them, this research employed mostly technical experts to evaluate those behaviors. Furthermore, the survey data from the origins were obtained at two separate times, which substantially reduces potential common method bias. (Podsakoff et al., 2012). However, this research suggested certain limitations. First, four separate organizations in the defense sector located in the capital city of Turkey provided the data and this may constrain the generalizability of the conclusions. Nevertheless, this research may be applied by performing comparative research through the participants employed by various kinds of organizations operating in other domains such as international, public and private sectors. Second, this research analyzed the mediating role of voice behavior between LMX and IWB. On the other hand, as a future research attempt, the LMX may also mediate the correlation amongst IWB and employee voice. Furthermore, the different attributes of LMX in this research introduced, to get a better understanding, forthcoming studies can look at the quality of several types of leadership types such as despotic, transactional, transformational, and ethical leadership on employee voice and IWB. Lastly, voice behavior is applied as a one-dimensional construct. Nevertheless, future research may explore the prohibitive and promotive voices to have a clear understanding of their stimulating structure.

\subsection{Conclusion}

Supporting SET, this research gives a clear picture to understand the high-quality reciprocating relationship with the supervisors and boost employee voice behaviors, which could encourage employee IWB within the workplace. The findings of this research will support researchers and practitioners in improving their understanding of why employees need to raise their voices and facilitate creating additional interest in voice behavior studies. Organizations should manage their employees to participate in recognizing difficulties and offering ideas for sustainable growth, and this research presents some implications for supporting employee voice. The significant impact of LMX on employee voice indicates that supervisors may encourage voice behavior by delivering support, confidence, esteem, mutual control, and efficient interaction with employees. Consequently, organizations have to urge leaders to create decent quality relationships with their subordinates and ascertain guidelines to foster the development of the relationships between the effective leader and the subordinates such as reciprocal valuation between leaders and subordinates.

\section{REFERENCES}

Abstein, A. and Spieth, P. (2014). Exploring HRM Meta-features that foster employees' innovative work behaviour in times of increasing work-life conflict, Creativity and Innovation Management, 23(2), 211225.

Adarves-Yorno, I., Postmes, T. and Haslam, S.A. (2007). Creative innovation or crazy irrelevance? The contribution of group norms and social identity to creative behavior, Journal of Experimental Social Psychology, 43(3), 410-416.

Amo, B.W. and Kolvereid, L. (2005). Organizational strategy, individual personality and innovation behavior, Journal of Enterprising Culture, 13(1), 7-19.

Anderson, N., Poto.cnik, K. and Zhou, J. (2014). Innovation and creativity in organizations: A state-of thescience review, prospective commentary, and guiding framework. Journal of Management, 40(5), 12971333.

Avey,J.B., Wernsing, T.S. and Palanski, M.E. (2012). Exploring the process of ethical leadership: The mediating role of employee voice and psychological ownership, Journal of Business Ethics, 107(1), 2134.

Bai, Y., Lin, L. and Li, P.P. (2016). How to enable employee creativity in a team context: A cross-level mediating process of transformational leadership, Journal of Business Research, 69(9), 3240-3250. 


\section{A. Sökmen - E. S. Mete 13/2 (2021) 1306-1321}

Baron, R. M. and Kenny, D. A. (1986). The moderator-mediator variable distinction in social psychological research: Conceptual, strategic, and statistical considerations. Journal of Personality and Social Psychology, 51(6), 1173-1182.

Basu, R. and Green, S.G. (1997). Leader-member exchange and transformational leadership: an empirical examination of innovative behaviors in leader-member dyads, Journal of Applied Social Psychology, 27(6), 477-499.

Bateman, T.S. and Crant, J.M. (1993). The proactive component of organizational behavior: A measure and correlates, Journal of Organizational Behavior, 14(2), 103-118.

Bauer, T.N. and Green, S.G. (1996). Development of leader-member exchange: a longitudinal test, Academy of Management Journal, 39(6), 1538-1567.

Blau, P.M. (1964). Exchange and power in social life, New York, NY, John Wiley and Sons.

Blau, T.H. (1984). Foreword in Kaslow, F. (Ed.) Psychotherapy with psychotherapists, New York, John Wiley and Sons.

Bos-Nehles, A.C. and Veenendaal, A.A. (2019). Perceptions of HR practices and innovative work behavior: the moderating effect of an innovative climate, International Journal of Human Resource Management, 30(18), 2661-2683.

Botero, I.C. and Van Dyne, L. (2009). Employee voice behavior: interactive effects of LMX and power distance in the United States and Colombia, Management Communication Quarterly, 23 (1), 84-104.

Burris, E.R., Detert, J.R. and Chiaburu, D.S. (2008). Quitting before leaving: the mediating effects of psychological attachment and detachment on voice, Journal of Applied Psychology, 93(4), 912-922.

Carnevale, J.B., Huang, L., Crede, M., Harms, P. and Uhl-Bien, M. (2017). Leading to stimulate employees' ideas: A quantitative review of leader-member exchange, employee voice, creativity, and innovative behavior, Applied Psychology, 66(4), 517-552.

Chan, S.C. (2014). Paternalistic leadership and employee voice: does information sharing matter?, Human Relations, 67(6), 667-693.

Chen, A.S.-Y. and Hou, Y.-H. (2016). The effects of ethical leadership, voice behavior and climates for innovation on creativity: A moderated mediation examination, The Leadership Quarterly, 27(1), 1-13.

Cheung, M.F. and Wong, C.-S. (2011). Transformational leadership, leader support, and employee creativity. The Leadership and Organization Development Journal, 32(7), 656-672.

Chowhan, J., Pries, F. and Mann, S. (2017). Persistent innovation and the role of human resource management practices, work organization, and strategy, Journal of Management and Organization, 23(3), 456-471.

Dansereau, F., Graen, G. and Haga, W.J. (1975). A vertical dyad linkage approach to leadership within formal organizations: A longitudinal investigation of the role making process, Organizational Behavior and Human Decision Processes, 13(1), 46-78.

De Jong, J.P. and Den Hartog, D.N. (2007). How leaders influence employees' innovative behavior, European Journal of Innovation Management, 10(1), 41-64.

Deci, E.L. and Ryan, R.M. (1987). The support of autonomy and the control of behavior, Journal of Personality and Social Psychology, 53(6), 1024.

Dedahanov, A.T., Lee, D.H., Rhee, J. and Yoon, J. (2016). Entrepreneur's paternalistic leadership style and creativity: The mediating role of employee voice, Management Decision, 54(9), 2310-2324.

Delmestri, G. and Walgenbach, P. (2005). Masteringtechniques or brokering knowledge? Middle managers in Germany, Great Britain and Italy, Organization Studies, 26, 197-220.

Denti, L. and Hemlin, S. (2012). Leadership and innovation in organizations: A systematic review of factors that mediate or moderate the relationship, International Journal of Innovation Management, 16(3), 124000-1- 124000-20.

Detert, J.R. and Burris, E.R. (2007). Leadership behavior and employee voice: is the door really open?, Academy of Management Journal, 50(4), 869-884. 


\section{A. Sökmen - E. S. Mete 13/2 (2021) 1306-1321}

Dienesch, R.M. and Liden, R.C. (1986). Leader-member exchange model of leadership: A critique and further development, Academy of Management Review, 11(3), 618-634.

Dulebohn, J.H., Bommer, W.H., Liden, R.C., Brouer, R.L. and Ferris, G.R. (2012). A meta-analysis of antecedents and consequences of leader-member exchange: Integrating the past with an eye toward the future, Journal of Management, 38(6), 1715-1759.

Dundon, T. and Dobbins, T. (2015). Militant partnership: A radical pluralist analysis of workforce dialectics, Work Employment and Society, 29(6), 912-931.

Dutton, J.E. and Ashford, S.J. (1993). Selling issues to top management, Academy of Management Review, 18(3), 397-428.

Dyne, L.V., Ang, S. and Botero, I.C. (2003). Conceptualizing employee silence and employee voice as multidimensional constructs, Journal of Management Studies, 40(6), 1359-1392.

Edmondson, A.C. (2003). Speaking up in the operating room: How team leaders promote learning in interdisciplinary action teams, Journal of Management Studies, 40(6), 1419-1452.

Fuller, J., Barnett, Hester, K. and Frey, L. (2007). An exploratory examination of voice behavior from a impression management perspective, Journal of Managerial Issues, 19(1), 134-151.

Gabris, G.T., Grenell, K., Ihrke, D.M. and Kaatz, J. (2000). Managerial innovation at the local level: Some effects of administrative leadership and governing board behavior, Public Productivity and Management Review, 23(4), 486-494.

Gerstner, C.R. and Day, D.V. (1997). Meta-Analytic review of leader-member exchange theory: Correlates and construct issues, Journal of Applied Psychology, 82(6), 827.

Gong, Y., Huang, J.C. and Farh, J.L. (2009). Employee learning orientation, transformational leadership, and employee creativity: The mediating role of employee creative self-efficacy, Academy of Management Journal, 52(4), 765-778.

Gouldner, A.W. (1960). The norm of reciprocity: a preliminary statement. American Sociological Review, 25(2), 161-178.

Graen, G.B. and Uhl-Bien, M. (1995). Relationship-based approach to leadership: development of leadermember exchange (LMX) theory of leadership over 25 years: Applying a multi-level multi domain perspective, The Leadership Quarterly, 6(2), 219-247.

Graham, J.W. and Van Dyne, L. (2006). Gathering information and exercising influence: Two forms of civic virtue organizational citizenship behavior, Employee Responsibilities and Rights Journal, 18(2), 89-109.

Grant, A.M. and Rothbard, N.P. (2013). When in doubt, seize the day? Security values, prosocial values, and proactivity under ambiguity, Journal of Applied Psychology, 98(5), 810-819.

Gu, J., Wang, G., Liu, H., Song, D. and He, C. (2018). Linking authoritarian leadership to employee creativity: The influences of leader-member exchange, team identification and power distance, Chinese Management Studies, 12(2), 384-406.

Gumusluoglu, L. and Ilsev, A. (2009). Transformational leadership and organizational innovation: The roles of internal and external support for innovation, Journal of Product Innovation Management, 26(3), 264277.

Guo, L., Decoster, S., Babalola, M.T., De Schutter, L., Garba, O.A. and Riisla, K. (2018). Authoritarian leadership and employee creativity: The moderating role of psychological capital and the mediating role of fear and defensive silence, Journal of Business Research, 92, 219-230.

Guzman, F.A. and Espejo, A. (2019). Introducing changes at work: how voice behavior relates to management innovation, Journal of Organizational Behavior, 40(1), 73-90.

Hammond, M.M., Neff, N.L., Farr, J.L., Schwall, A.R. and Zhao, X. (2011). Predictors of individual-level innovation at work: a meta-analysis, Psychology of Aesthetics, Creativity, and the Arts, 5(1), 90-102.

Hassanzadeh, J.F. (2014). Leader-member exchange and creative work involvement: The importance of knowledge sharing. Iranian Journal of Management Studies, 7(2), 377-396. 


\section{A. Sökmen - E. S. Mete 13/2 (2021) 1306-1321}

Hayes, A. F. (2009). Beyond Baron and Kenny: Statistical mediation analysis in the new Millennium. Communication Monographs, 76(4), 408-420.

Hsiung, H.H. (2012). Authentic leadership and employee voice behavior: a multi-level psychological process, Journal of Business Ethics, 107(3), 349-361.

Hsiung, H.H. and Tsai, W.C. (2009). Job definition discrepancy between supervisors and subordinates: the antecedent role of LMX and outcomes, Journal of Occupational and Organizational Psychology, 82(1), 89112.

Huang, X., Van de Vliert, E. and Van der Vegt, G. (2005). Breaking the silence culture: Stimulation of participation and employee opinion withholding cross-nationally. Management and Organization Review, 1(3), 459-482.

Ilies, R., Nahrgang, J.D. and Morgeson, F.P. (2007). Leader-member exchange and citizenship behaviors: a Meta-analysis, Journal of Applied Psychology, 92(1), 269-277.

Janssen, O. (2000). Job demands, perceptions of effort-reward fairness and innovative work behavior, Journal of Occupational and Organizational Psychology, 73(3), 287-302.

Janssen, O. and Van Yperen, N.W. (2004). Employees' goal orientations, the quality of leader-member exchange, and the outcomes of job performance and job satisfaction. Academy of Management Journal, 47(3), 368-384.

Javed, B., Naqvi, S.M.M.R., Khan, A.K., Arjoon, S. and Tayyeb, H.H. (2017). Impact of inclusive leadership on innovative work behavior: The role of psychological safety, Journal of Management and Organization, 25(1), 1-20.

Kremer, H., Villamor, I. and Aguinis, H. (2019). Innovation leadership: Best-practice recommendations for promoting employee creativity, voice, and knowledge sharing, Business Horizons, 62(1), 65-74.

Le Pine, J.A. and Van Dyne, L. (2001). Voice and cooperative behavior as contrasting forms of contextual performance: Evidence of differential relationships with big five personality characteristics and cognitive ability, Journal of Applied Psychology, 86(2), 326.

Lee, J. (2008). Effects of leadership and leader-member exchange on innovativeness, Journal of Managerial Psychology, 23(6), 670-687.

Li, H., Sajjad, N., Wang, Q., Muhammad Ali, A., Khaqan, Z. and Amina, S. (2019). Influence of transformational leadership on employees' innovative work behavior in sustainable organizations: Test of mediation and moderation processes, Sustainability, 11(6), 1594.

Liang, J., Farh, C.I. and Farh, J.-L. (2012). Psychological antecedents of promotive and prohibitive voice: A two-wave examination, Academy of Management Journal, 55(1), 71-92.

Liden, R. C. and Maslyn, J. M. (1998). Multi-dimensionality of leader-member exchange: An empirical assessment through scale development, Journal of Management, 24(1), 43-72.

Liu, W., Zhu, R. and Yang, Y. (2010). I warn you because I like you: Voice behavior, employee identifications, and transformational leadership, The Leadership Quarterly, 21(1), 189-202.

Mackey, J.D., Huang, L. and He, W. (2018). You abuse and I criticize: An ego depletion and leader-member exchange examination of abusive supervision and destructive voice, Journal of Business Ethics, 164, 113.

Martins, E.C. and Terblanche, F. (2003). Building organisational culture that stimulates creativity and innovation, European Journal of Innovation Management, 6(1), 64-74.

Masood, M. and Afsar, B. (2017). Transformational leadership and innovative work behavior among nursing staff, Nursing Inquiry, 24(4), e12188.

Miao, Q., Newman, A., Schwarz, G. and Cooper, B. (2018). How leadership and public service motivation enhance innovative behavior, Public Administration Review, 78(1), 71-81.

Mo, S. and Shi, J. (2018). The voice link: A moderated mediation model of how ethical leadership affects individual task performance, Journal of Business Ethics, 152(1), 91-101.

Morrison, E.W. (2011). Employee voice behavior: Integration and directions for future research, The Academy of Management Annals, 5(1), 373-412. 


\section{A. Sökmen - E. S. Mete 13/2 (2021) 1306-1321}

Morrison, E.W. (2014). Employee voice and silence, Annual Review of Organizational Psychology and Organizational Behavior, 1(1), 173-197.

Morrison, E.W. and Milliken, F.J. (2000). Organizational silence: A barrier to change and development in a pluralistic world, Academy of Management Review, 25(4), 706-725.

Morrison, E.W. and Milliken, F.J. (2003). Speaking up, remaining silent: The dynamics of voice and silence in organizations, Journal of Management Studies, 40(6), 1353-1358.

Mowday, R.T., Porter, L.W. and Steers, R.M. (2013). Employee-organization Linkages: The psychology of commitment, absenteeism, and turnover, New York, NY, Academic Press.

Muñoz-Doyague, M.F. and Nieto, M. (2012). Individual creativity performance and the quality of interpersonal relationships, Industrial Management \& Data Systems, 112(1), 125-145.

Ng, K.-Y., Van Dyne, L. and Ang, S. (2019). Speaking out and speaking up in multicultural settings: A twostudy examination of cultural intelligence and voice behavior, Organizational Behavior and Human Decision Processes, 151, 150-159.

Ng, T.W. and Feldman, D.C. (2012). Employee voice behavior: A meta-analytic test of the conservation of resources framework, Journal of Organizational Behavior, 33(2), 216-234.

Oldham, G.R. and Cummings, A. (1996). Employee creativity: Personal and contextual factors at work, Academy of Management Journal, 39(3), 607-634.

Organ, D.W., Podsakoff, P.M. and MacKenzie, S.B. (2005). Organizational citizenship behavior: Its nature, antecedents, and consequences, Thousand Oaks, CA, Sage Publications.

Podsakoff, P.M., MacKenzie, S.B. and Podsakoff, N.P. (2012). Sources of method bias in social science research and recommendations on how to control it, Annual Review of Psychology, 63, 539-569.

Rank, J., Pace, V.L. and Frese, M. (2004) Three avenues for future research on creativity, innovation, and initiative, Applied Psychology, 53(4), 518-528.

Saeed, B.B., Afsar, B., Cheema, S. and Javed, F. (2019). Leader-member exchange and innovative work behavior: The role of creative process engagement, core self-evaluation, and domain knowledge, European Journal of Innovation Management, 22(1), 105-124.

Schermuly, C.C., Meyer, B. and Dämmer, L. (2013). Leader-member exchange and innovative behavior, Journal of Personnel Psychology, 12(3), 132-142.

Schuh, S.C., Zhang, X.A., Morgeson, F.P., Tian, P. and van Dick, R. (2018). Are you really doing good things in your boss's eyes? Interactive effects of employee innovative work behavior and leader-member exchange on supervisory performance ratings, Human Resource Management, 57(1), 397-409.

Scott, S.G. and Bruce, R.A. (1994). Determinants of innovative behavior: A path model of individual innovation in the workplace, Academy of Management Journal, 37(3), 580-607.

Serva, M.A., Fuller, M.A. and Mayer, R.C. (2005). The reciprocal nature of trust: A longitudinal study of Interacting teams, Journal of Organizational Behavior: The International Journal of Industrial, Occupational and Organizational Psychology and Behavior, 26(6), 625-648.

Singh, M. and Sarkar, A. (2012). The relationship between psychological empowerment and innovative behavior, Journal of Personnel Psychology, 11(3), 127-137.

Slåtten, T., Svensson, G. and Sværi, S. (2011). Empowering leadership and the influence of a humorous work climate on service employees' creativity and innovative behaviour in frontline service jobs, International Journal of Quality and Service Sciences, 3 (3), 267-284.

Tangirala, S. and Ramanujam, R. (2008). Exploring nonlinearity in employee voice: The effects of personal control and organizational identification, Academy of Management Journal, 51(6), 1189-1203.

Tierney, P. (2008). Leadership and employee creativity, Zhou, J. and Shalley, C.E. (Eds.), Handbook of organizational creativity, New York, NY, Erlbaum, 95-123.

Uhl-Bien, M., Graen, G.B. and Scandura, T.A. (2000). Implications of leader-member exchange (LMX) for strategic human resource management systems: Relationships as social capital for competitive advantage, Research in Personnel and Human Resources Management, 18(1), 137-185. 


\section{A. Sökmen - E. S. Mete 13/2 (2021) 1306-1321}

Van Dyne, L. and Le Pine, J.A. (1998). Helping and voice extra-role behaviors: evidence of construct and predictive validity, Academy of Management Journal, 41(1), 108-119.

Van Dyne, L., Ang, S. and Botero, I. (2003). Conceptualizing employee silence and employee voice as multi-dimensional constructs, Journal of Management Studies, 40(6), 34.

Van Dyne, L., Kamdar, D. and Joireman, J. (2008). In-role perceptions buffer the negative impact of low LMX on helping and enhance the positive impact of high LMX on voice, Journal of Applied Psychology, 93(6), 1195-1207.

Volmer, J., Spurk, D. and Niessen, C. (2012). Leader-member exchange (LMX), job autonomy, and creative work involvement, The Leadership Quarterly, 23(3), 456-465.

Walumbwa, F.O. and Schaubroeck, J. (2009). Leader personality traits and employee voice behavior: mediating roles of ethical leadership and work group psychological safety, Journal of Applied Psychology, 94(5), 1275.

Wang, Y., Tang, C., Naumann, S.E. and Wang, Y. (2017). Paternalistic leadership and employee creativity: A mediated moderation model, Journal of Management and Organization, 25(1), 1-20.

Weiss, M. and Morrison, E.W. (2019). Speaking up and moving up: how voice can enhance employees' social status, Journal of Organizational Behavior, 40(1), 5-19.

Whiting, S.W., Maynes, T.D., Podsakoff, N.P. and Podsakoff, P.M. (2012). Effects of message, source, and context on evaluations of employee voice behavior, Journal of Applied Psychology, 97(1), 159-182.

Wijaya, N.H.S. (2019). Proactive personality, LMX, and voice behavior: Employee-supervisor sex (dis) similarity as a moderator, Management Communication Quarterly, 33 (1), 86-100.

$\mathrm{Wu}, \mathrm{T}$. and $\mathrm{Wu}, \mathrm{Y}$. (2019). Innovative work behaviors, employee engagement, and surface acting: A delineation of supervisor-employee emotional contagion effects, Management Decision, 57(11), 32003216.

Yukl, G. (2002), Leadership in organizations (5th ed). Upper Saddle River, NJ, Prentice-Hall.

Zhang, X. and Bartol, K.M. (2010). Linking empowering leadership and employee creativity: The influence of psychological empowerment, intrinsic motivation, and creative process engagement, Academy of Management Journal, 53(1), 107-128.

Zhang, Y., Huai, M.-Y. and Xie, Y.-h. (2015). Paternalistic leadership and employee voice in China: A dual process model, The Leadership Quarterly, 26(1), 25-36.

Zhang, A.Y., Tsui, A.S., Song, L.J., Li, C. and Jia, L. (2008). How do I trust thee? The employee organization relationship, supervisory support, and middle manager trust in the organization, Human Resource Management, 47(1), 111-132.

Zhou, J. and George, J.M. (2001). When job dissatisfaction leads to creativity: Encouraging the expression of voice, Academy of Management Journal, 44(4), 682-696. 